\title{
The Effect of Storage and Age of Hens on the Quality of Table Eggs
}

\author{
Lidija Perić *, Mirjana Đukić Stojčić, Siniša Bjedov
}

University of Novi Sad, Faculty of Agriculture, 21000 Novi Sad, Trg Dositeja Obradovića 8, Srbija

Accepted June, 2017

\begin{abstract}
Quality of poultry products, especially eggs, is a very important issue for the consumers and for the processing industry. The aim of the present study was to examine the interaction between the storage time and age of laying hens and their effect on the quality of table eggs. Eggs from 34 and 59- wk-old Bovans Brown hens were sampled and stored in the refrigerator for 1,2 , and 3 weeks. Significant effect of hen age $(P<0.01)$ was found on egg weight, shell strength, albumen height and Haugh units $(\mathrm{HU})$. Eggs from older hens had $2.58 \%$ higher mass compared to the eggs of young hens. Eggs from 59-weeks old hens had significantly lower shell strength (3.63 kg vs. $4.31 \mathrm{~kg})$. Albumen height and $\mathrm{HU}$ were lower in eggs from the older hens compared to the young ones $(5.7 \mathrm{~mm}$ vs. $7.11 \mathrm{~mm}$ for albumen height; 70.35 vs. 81.77 for HU). Significant negative effect of storage time was found on egg weight, albumen height, $\mathrm{HU}$ and yolk colour $(\mathrm{P}<0.01)$. The results indicated that egg quality characteristics monitored in this study decrease by hen age and during storage. The interaction effects between storage time and age of hens were significant only for yolk colour $(\mathrm{P}<0.05)$.
\end{abstract}

Keywords: age, egg quality, hen, storage.

\section{Introduction}

The egg quality is one of the most important parameters for both the producers and consumers. Exterior quality traits of eggs are very important for the producers, whereas the interior quality of eggs is crucial for the consumers and the industry [1]. This is especially related to the quality of the egg white, which depends on several factors, such as genetic factors [2,3], nutrition [4], the age of laying hens [2,5] and the duration of the storage period [1,6]. During the storage period, the $\mathrm{pH}$ value of the egg white is increased, which negatively affects its quality [7]. The quality of the yolk is determined by two traits: yolk colour and the firmness of the previtelline membrane. Both traits are influenced by the age of laying hens, nutrition and storage conditions. During the storage period, the previtelline

\section{* Corresponding author: Lidija Perić, lidija.peric@stocarstvo.edu.rs}

(Cc) BY-NC-ND @ 2017 Lidija Perić et al., published by De Gruyter Open. This work was licensed under the Creative Commons Attribution-NonCommercialNoDerivs 3.0 License membrane becomes weaker and can even rupture [8].

Concerning the exterior egg quality traits, the most important ones are the eggshell cleanliness and shell strength. The eggshell cleanliness is mostly affected by the housing system, while the eggshell strength is primarily affected by the genotype [1], nutrition [9, 10, 11] and the age of laying hens [12]. The effect of the storage process on the eggshell strength and cleanliness is generally not significant.

The aim of this research was to determine the influence of the age of laying hens and the duration of the storage period on the quality of table eggs, as well as to determine whether these factors interact in any way.

\section{Material and Methods}

The eggs used in this study were obtained from Bovans Brown hens, which were housed in conventional cages on a commercial farm. Two flocks of different age were housed in two separated environmentally controlled poultry houses. Feed and water were offered ad libitum. The photoperiod at time of lay was $16 \mathrm{~h}$ light: $8 \mathrm{~h}$ 
dark. The hens were fed a mashed diet and all nutrient levels met the nutrient requirements suggested in the Bovans Brown Management Guide [13].

Total of 240 eggs from 34 and 59- week-old hens were sampled immediately after being laid and subjected to storage. 120 eggs for each hen age were stored inside a refrigerator $\left(5^{\circ} \mathrm{C}\right)$ and stored for the periods of 1,2 , and 3 weeks. The samples of 30 eggs of both age were analysed at the beginning (day 0 ) and after each period of storing. Eggs were examined for egg weight, albumen height, Haugh units (HU) and yolk colour.

Egg weight was measured on a precision scale. All eggs were measured on the first day and the weight losses were calculated as a difference between the weight on the first day and the weight after storage. Shell breaking force was determined by instrument Egg Force Reader (Orka Food Technology Ltd, Israel). Yolk colour was determined using the Roche yolk colour fan. Albumen height was measured with a tripod micrometer. On the basis of egg mass (M) and albumen height $(\mathrm{H})$, Haugh units were calculated according to formula $\mathrm{HU}=100 \mathrm{log} \quad(\mathrm{H}+7.57-$ $1.7 \mathrm{M}^{0.37}$ ).

Data collected during the study were subjected to an ANOVA utilizing the GLM analysis in STATISTICA 13 (Stat Soft, 2016). The model included the main effects of the storage times and age of hen, and the two-way interactions

between these factors. When the effects of the main factors were significant, the means were separated using Duncan's test. Probabilities of less than 0.05 were considered significant for all analyses.

\section{Results and Discussions}

The results of the research indicate the significant influence of the examined factors on the egg quality traits (table 1). The age of laying hens had a highly significant influence on the egg mass $(P<0.001)$. Eggs from the older hens had $2.58 \%$ higher mass compared to the eggs of young hens. Roberts [1] emphasizes that the age of laying hens is the basic factor that affects the egg mass which increases with the age of laying hens.

Egg quality traits at 34 and 59 weeks of hen's age $(\bar{x})$

Table 1

\begin{tabular}{|c|c|c|c|c|c|c|c|}
\hline \multirow[b]{2}{*}{$\begin{array}{l}\text { Age of } \\
\text { hens, } \\
\text { weeks }\end{array}$} & \multirow[b]{2}{*}{$\begin{array}{l}\text { Storage } \\
\text { length, } \\
\text { weeks }\end{array}$} & \multicolumn{6}{|c|}{ Characteristics } \\
\hline & & $\begin{array}{c}\text { Egg } \\
\text { weight }(g)\end{array}$ & $\begin{array}{l}\text { Weight } \\
\text { loss (g) }\end{array}$ & $\begin{array}{c}\text { Shell } \\
\text { breaking } \\
\text { force }(\mathrm{kg})\end{array}$ & $\begin{array}{c}\text { Albumen } \\
\text { heigth }(\mathrm{mm})\end{array}$ & Haugh units & Yolk color \\
\hline \multirow{5}{*}{34} & 0 & 63.53 & - & 4.21 & $8.18^{\mathrm{a}}$ & $89.07^{\mathrm{a}}$ & $14.03^{\mathrm{a}}$ \\
\hline & 1 & 63.75 & $0.178^{\mathrm{a}}$ & 4.52 & $7.90^{\mathrm{a}}$ & $86.98^{\mathrm{a}}$ & $13.93^{\mathrm{ab}}$ \\
\hline & 2 & 63.82 & $0.744^{\mathrm{b}}$ & 4.20 & $7.08^{\mathrm{b}}$ & $81.56^{\mathrm{b}}$ & $13.89^{\mathrm{ab}}$ \\
\hline & 3 & 62.68 & $0.996^{\mathrm{C}}$ & 4.32 & $5.30^{\mathrm{c}}$ & $69.47^{\mathrm{C}}$ & $13.65^{\mathrm{b}}$ \\
\hline & SEM & 0.475 & 0.022 & 0.078 & 0.151 & 1.025 & 0.061 \\
\hline \multirow{5}{*}{59} & 0 & 67.37 & - & 3.42 & $6.69^{\mathrm{a}}$ & $78.15^{\mathrm{a}}$ & $14.44^{\mathrm{a}}$ \\
\hline & 1 & 66.10 & $0.261^{\mathrm{a}}$ & 3.82 & $6.44^{\mathrm{a}}$ & $76.78^{\mathrm{a}}$ & $13.80^{\mathrm{a}}$ \\
\hline & 2 & 65.16 & $0.962^{b}$ & 3.63 & $5.45^{\mathrm{b}}$ & $68.94^{\mathrm{b}}$ & $13.13^{\mathrm{b}}$ \\
\hline & 3 & 65.70 & $1.162^{\mathrm{b}}$ & 3.54 & $4.22^{\mathrm{C}}$ & $56.27^{\mathrm{C}}$ & $13.50^{\mathrm{ab}}$ \\
\hline & SEM & 0.447 & 0.036 & 0.081 & 0.488 & 1.721 & 0.063 \\
\hline \multicolumn{8}{|c|}{$P$ value for the main effects ${ }^{*}$} \\
\hline \multicolumn{2}{|c|}{ Age of hens } & $<0.01$ & $<0.01$ & $<0.01$ & $<0.01$ & $<0.01$ & 0.279 \\
\hline \multicolumn{2}{|c|}{ Storage length } & 0.104 & $<0.01$ & 0.121 & $<0.01$ & $<0.01$ & $<0.01$ \\
\hline \multicolumn{2}{|c|}{ Interactions } & 0.352 & 0.253 & 0.852 & 0.693 & 0.914 & 0.046 \\
\hline
\end{tabular}

$\left({ }^{a, b, c}\right)$ Different letters indicate significant differences among the means in each column with the same age ${ }^{*} P$ values $<0.01$ are statistically significant

SEM - Standard error of means

The eggshell firmness was under the significant influence of hens age. Eggs from 59-weeks old hens had significantly lower shell strength (3.63 $\mathrm{kg}$ ) compared to the eggs from younger flock $(4.31 \mathrm{~kg})$. Rodriguez-Navarro et al. [14] stated that eggshells from aged hens had a lower breaking strength (less than half that of those laid by young hens) and show a greater variability in their structural properties such as thickness, grain morphology and crystallographic texture. 
The albumen quality was also affected by hens age. Concerning the egg white quality, in healthy flocks, bird age is the most important factor affecting albumen quality of freshly laid eggs [5]. Albumen height and $\mathrm{HU}$ were lower in eggs from the older hens compared to the young ones (5.7 $\mathrm{mm}$ vs. $7.11 \mathrm{~mm}$ for albumen height; 70.35 vs. 81.77 for HU). Aykerek and Okur [12] reported that $\mathrm{HU}$ decreased in 22 weeks old hens age from 91.48 to 52.11 during 14 days of storage, whereas at 50 weeks of age $\mathrm{HU}$ declined from 81.53 to 32.55 .

The duration of the storage period also had a significant effect on the egg mass loss, egg white quality, and yolk colour. Average loss of the egg weight during storage was higher in old flock $\left(1.162 \mathrm{~g}\right.$ in $3^{\text {rd }}$ week) compared to young flock $\left(0.996 \mathrm{~g}\right.$ in $3^{\text {rd }}$ week). This is related to the deterioration of egg shell properties during aging of hens [14]. In the paper published by Aykerek and Okur [12] the higher duration of the storage period led to the higher egg mass loss, which was larger under the higher temperature of storage. As opposed to these authors, Scott and Silverside [7] did not determine the egg mass loss in the eggs stored for 10 days.

The egg white quality significantly decreased during the storage period both in young and old flocks. Significant negative effect on HU was determined after two weeks of storage, and after the third week the quality further deteriorated (from 89.07 to 69.47 for young hens; from 78.15 to 56.27 for older hens). There was no interaction between the flock age and the duration of the storage for albumen height or HU. The primary cause of the decrease in Haugh units during storage is the loss of water and carbon-dioxide from the egg white during the storage period. As a consequence, the egg mass loss and the decrease in the egg white quality took place $[5,7$, 12].

Considering the yolk colour, it was reduced during storage from 14.03 to 13.65 in young flock and from 14.44 to 13.50 in older flock. Similar to these results, Jin et al. [6] determined significant changes in yolk colour after only two days of storage under the temperature of $29^{\circ} \mathrm{C}$. Maria Elena et al. [15] also determined that the changes in yolk colour occurred under high temperatures of storage $\left(20^{\circ} \mathrm{C}\right)$, but that under lower temperatures $\left(4^{\circ} \mathrm{C}\right)$ no changes in yolk colour occurred even after 30 days. The reasons for such yolk colour changes could be explained by the fact that, over a period of time, the degeneration of the previtalline membrane takes place, so the water from the egg white enters the yolk and dilutes the pigment [16]. If the storage period is longer, some proteins from the egg white can also breach into the yolk and cause the decrease in yolk colour. The interaction effects between storage time and age of hens were significant only for yolk colour.

\section{Conclusions}

The results indicate that egg weight, albumen height, $\mathrm{HU}$ and yolk colour are parameters that are greatly influenced by the age of hens and storage length. Generally, the results of this work confirmed that quality of table eggs decrease by hen age and during storage.

\section{Acknowledgements}

Research was financed by the Ministry of Science and Technological Development, Republic of Serbia, project TR 31033.

\section{References}

1. Roberts, J.R. (2004). Factors affecting internal quality and egg shell quality in laying hens. Journal of Poultry Science, 41 (3), 161-177.

2. Silversides, F. G. \& Scott. T. A. (2001). Effect of storage and layer age on quality of eggs from two lines of hens. Poultry Science, 80, 1240-1245.

3. Johnson, A. S. \& Merritt, E. S. (1955). Heritability of albumen height and specific gravity of eggs from White Leghorns and Barred Rocks and the correlations of these traits with egg production. Poultry Science, 34, 578-587. https://doi.org/10.3382/ps.0340578

4. Franchini, A., Sirri, F., Tallarico, N., Minelli, G., laffaldano, N. \& Meluzzi, A. (2002). Oxidative stability and sensory and functional properties of eggs from laying hens fed supranutritional doses of vitamins $E$ and C. Poultry Science, 81, 1744-1750. https://doi.org/10.1093/ps/81.11.1744

5. Samli, H.E., Agma, A. \& Senkoylu, N. (2005). Effects of storage time and temperature on egg quality in old laying hens. Journal of Applied Poultry Research, 14, 548-553.

6. Jin, Y.H., Lee, K.T., Lee, W.I. \& Han, Y.K. (2011). Effect of storage temperature and time on the quality of eggs from laying hens at peak production. AsianAustralian Journal of Animal Science, 24, 279-284. https://doi.org/10.5713/ajas.2011.10210

7. Scott, T. A. \& Silversides, F. G. (2000). The effect of storage and strain of hen on egg quality. Poultry Science, 79,1725-1729.

8. Kirunda, D.F.K. \& McKee, S.R. (2000). Relating quality characteristics of aged eggs and fresh eggs to vitelline membrane strength as determined by a texture analyser. Poultry Science, 79, 1189-1193.

9. Bar, A, Razaphkovsky, V. \& Vax, E. (2002). Reevaluation of calcium and phosphorus requirements in aged in laying hens. British Poultry Science, 43, 261269. http://dx.doi.org/10.1080/00071660120121481

10. Sohail, S.S. \& Roland, D.A. (2002). Influence of dietary phosphorus on performance of Hy-Line W-0 hens. Poultry Science, 81, 75-83.

11. Jamroz, D, Orda, J, Skorupinska, J, Wiliczkiewicz, A, Wertelecki, T, Zylka, R \& Klunter, AM. (2003). Reaction of laying hens to low phosphorus 
diets and addition of different phytase preparations. Journal of Animal and Feed Sciences, 12, 95-110. https://doi.org/10.22358/jafs/67664/2003

12. Akyurek, H. \& Okur, A.A. (2009). Effect of storage time, temperature and hen age on egg quality in free range layer hens. Journal of Animal and Veterinary Advances, 8 ,

1953-1958. https://doi.org/10.1093/japr/14.3.548

13. http://www.hendrixisa.com/en/isapoultry/products/bovans/bovans-brown/ 14. Rodriguez-Navarro A., Kalin O., Nys Y. \& GarciaRuiz J.M. (2002). Influence of the microstructure on the shell strength of eggs laid by hens of different ages.
British Poultry Science, 43, 395-403. https://doi.org/10.1080/00071660120103675

15. Maria Elena, C. J., Leonor, S. G., Eduardo, M. B., Silvia, C. D., Avila, A. G., Benjamin, F. M., Miriam, R. P. \& Fernando P. G. R. (2006). Shrimp head meal in laying hen rations and its effects on fresh and stored egg quality. 2006. INCL.

31 :http://www.scielo.org.ve/scielo.php?pid=S0378-

18442006001100009\&script=sci_arttext

16. Ahn, D. U., Sell, J. L., Jo, C., Chamruspollert, M. \& Jeffrey, M. (1999). Effects of dietary conjugated linoleic acid on the quality characteristics of chicken eggs during refrigerated storage. Poultry Science, 78, 922-928. 